\title{
Relationship Between Metal Load (Selenium, Arsenic, Molybdenum) of Soil, Plant and Serum of Buffaloes
}

\author{
ZAFAR IQBAL KHAN ${ }^{1 *}$, KAFEEL AHMAD ${ }^{1}$, NAUNAIN MEHMOOD ${ }^{2}$, ASIA FARDOUS ${ }^{1}$, \\ YONGJUN YANG ${ }^{3}$, JING MA ${ }^{3}$, TASNEEM AHMAD ${ }^{4}$, FU CHEN ${ }^{3}$, SUMAIRA GONDAL ${ }^{1}$, \\ KINZA WAJID ${ }^{1}$, IFRA SALEEM MALIK ${ }^{1}$, MUDASRA MUNIR ${ }^{1}$, IJZA RASOOL NOORKA ${ }^{\mathbf{5}}$, \\ MUHAMMAD FAHAD ULLAH ${ }^{6}$, HUMAYUN BASHIR ${ }^{1}$, \\ MOHAMMAD REZA KOUHKAN NEJAM ${ }^{7}$, ALI-REZA BAYAT ${ }^{7}$ \\ ${ }^{1}$ Department of Botany, University of Sargodha, Sargodha, 40100, Pakistan \\ ${ }^{2}$ Department of Zoology, University of Sargodha, 40100, Sargodha, Pakistan, \\ ${ }^{3}$ School of Environment Science and Spatial Informatics, China University of Mining and Technology, Xuzhou, China \\ ${ }^{4}$ Pakki Thatti R \& D Farm, Toba Tek Singh, Pakistan \\ ${ }^{5}$ University College of Agriculture, University of Sargodha, Pakistan \\ ${ }^{6}$ Department of Earth Sciences, University of Sargodha, Sargodha, Pakistan \\ ${ }^{7}$ Milk Production, Production Systems, Natural Resources Institute Finland (Luke), 31600 Jokioinen, Finland
}

\begin{abstract}
Presence of hazardous minerals in three major components (soil, forage and buffalo serum) was evaluated for determining extent of metal contamination in Sargodha, Pakistan. Ten soil and forage samples for each season were taken from ten randomly selected sites. 30 grazing buffaloes of 'niliravi' breed (calves, non-lactating and lactating) were also sampled randomly from these sites for collection of serum. Heavy metal quantification via atomic absorption spectrophotometry was carried out for selenium, molybdenum and arsenic. Non-significant but positive correlation was found for selenium (Se) concentrations in soil, forage and serum and molybdenum (Mo) concentrations in soil and serum. Negative correlation ( $p>0.05)$ was obtained for Mo level between forage-serum and soilforage which was indicative of molybdenum deficiency in the soil. The results suggested that the heavy metals remained below maximum permissible levels and were non-toxic for the ruminants of the study area.
\end{abstract}

Keywords: heavy metals, toxicity, soil, Niliravi buffalo, forage, serum

\section{Introduction}

Livestock productivity and nutritional status are dependent upon balanced provision of all the minerals and food components in diet [1]. With growing population and issues of food security, burden on agriculture and livestock sector has increased manifolds. A major share in coping with food scarcity issues is of livestock production field [2]. It is of utmost importance to assess nutritional and health status of ruminants to ensure maximum productivity. Animals need different metals in varying concentrations necessary for normal physiological functioning. Selenium (Se) as a constituent of glutathione peroxidase is an important part of cycle involving reduction of hydrogen peroxide. Se deficient animals exhibit hepatosis dietetica and liver necrosis, which is often fatal. Swine mulberry heart disease is triggered by low Se and vitamin E levels in the body causing pigs to die in young age [3]. Benefits of arsenic have been reported in literature for animal health and performance. Arsenic acts similarly to antibiotics in controlling harmful microbes in intestines [4].

Another essential micronutrient for animal and plant growth is molybdenum (Mo). In plants, Mo helps in nitrogen fixation and assimilation being a part of nitrate reductase [5].

The current study was aimed at investigating and evaluating the mineral status of forage and soil of livestock rich agricultural region of Pakistan in order to assess mineral bioavailability. Moreover, evaluation of the similar minerals in ruminants was also done in order to determine the health risk among ruminants (Niliravi buffalo) of that area. The information presented in this study would be

*email: zikhan11@gmail.com 
helpful for livestock rearing areas of Pakistan and other Asian countries with similar environmental conditions.

\section{Materials and methods}

\subsection{Study Site}

The dairy farm of Fodder Research Institute (FRI), Sargodha and associated farm lands were selected as the study site. Sargodha is predominantly agricultural area of Pakistan with extended summer season and short winter season. Mean summer and winter temperatures have a great fluctuation ranging between 14 to $35^{\circ} \mathrm{C}$. Farm lands were cultivated with different forage species, namely Sarso (Brassica compestris), oat (Avanasarivxa)and Barsem (Trifolium alexander). Soil and forage samples were taken from the farm lands while blood was collected from the Niliravi buffalo at the farm.

\subsection{Sample collection}

Ten randomly selected sites separated by the distance of 1 acre were chosen for the soil and forage sample collection. Soil samples (10) were collected from $12-15 \mathrm{~cm}$ depth, by stainless steel auger, partially containing all soil layers [6]. Likewise, the forage samples were collected from the farm lands during summer and winter seasons. The samples were given a wash in distilled water and dilute $\mathrm{HCl}$ for removal of dust residues and other contaminants. Moisture removal was achieved for soil and forage samples via air drying and subsequent oven drying at $50^{\circ} \mathrm{C}$ for 15 days.

Three cohorts of buffaloes (calves, non-lactating and lactating) were made for collection of blood samples during summer and winter. Ten buffaloes were sampled from each group and the blood was collected from the jugular vein with the help of sterilized needle. To prevent clotting, blood was quickly shifted to heparinized Na-Citrate vials. Serum separation from plasma was achieved after centrifugation (3000 rpm) for half hour. After successful separation, the serum was placed in labeled vials and stored in freezer till further use.

\subsection{Sample preparation}

All samples (soil, forage and serum) were digested following the protocol prescribed by Ugulu et al. [7]. Dry samples (forage and soil) were taken in $1 \mathrm{~g}$ quantity while serum sample was taken in $1 \mathrm{~mL}$ quantity to be digested with $\mathrm{H}_{2} \mathrm{O}_{2}$ and $\mathrm{H}_{2} \mathrm{SO}_{4}(2: 1)$. The sample, after complete digestion, was filtered using Whatman filter paper \# 42. Final volume of $50 \mathrm{~mL}$ was made for each sample after adding required amount of double distilled water.

\subsection{Mineral analysis}

Mo contents of soil, forage and serum were determined using AAS equipped with $\mathrm{D}_{2}$ corrector and graphite furnace. Fluorometric method was used along with injection hydride generation AAS to determine As and Se in the samples [8].

\subsection{Statistical analysis}

Data were subjected to the statistical analysis using the SPSS software for one-way ANOVA, correlation and bioconcentration factor (BCF) keeping significance level at 0.001, 0.01 and 0.05 [9].

\section{Results and discussions Mineral analysis Soil}

Sampling seasons had considerable $(p<0.001)$ variation with respect to Se concentration in soil (Table 1). Se level varied between 0.361 and $0.465 \mathrm{mg} / \mathrm{kg}$ in summer and winter respectively (Figure 1). These values were slightly below the critical value for $\mathrm{Se}(0.5 \mathrm{mg} / \mathrm{kg})$ in soils [10] indicating deficiency of Se at all locations. A similar study at adjoining city of Jhang, revealed high Se level 
$(0.70-0.94 \mathrm{mg} / \mathrm{kg})$ is soil [11] in comparison to present investigation. Low Se level is also reported in other studies carried out by Khan et al. $[12,13]$ in Punjab, Pakistan. Current study Se values, on the other hand, were lower than the findings of Kunliet al. [14]. Excessive or lower amount of Se in animals depend upon the bioavailable amount of Se to the plants [15].

Table 1. One-way ANOVA for metal concentrations in soil, forage and serumduring winter and summer seasons

\begin{tabular}{|c|c|c|c|c|c|c|c|}
\hline \multirow{3}{*}{\multicolumn{2}{|c|}{ Source of variation }} & \multirow{3}{*}{$\begin{array}{c}\text { Degree } \\
\text { Of freedom } \\
\text { (df) }\end{array}$} & \multirow{3}{*}{ Soil } & \multirow{3}{*}{ Forage } & \multirow{2}{*}{\multicolumn{3}{|c|}{ Serum }} \\
\hline & & & & & & & \\
\hline & & & & & Lactating & Dry & Calves \\
\hline \multirow{3}{*}{$\begin{array}{l}\text { Sampling } \\
\text { Period }\end{array}$} & $\mathrm{Se}$ & \multirow{3}{*}{1} & $0.045^{* * *}$ & $0.051^{\mathrm{ps}}$ & $0.003^{\mathrm{ns}}$ & $0.015^{* * *}$ & $0.001 * * *$ \\
\hline & As & & $0.078^{n 5}$ & $0.039^{\mathrm{n}}$ & $0.001^{\mathrm{ns}}$ & $0.006^{* *}$ & $0.003^{* *}$ \\
\hline & Mo & & $0.020^{\mathrm{ns}}$ & $3.698^{\mathrm{ns}}$ & $1.568 * *$ & $5.778^{* * *}$ & $0.903^{\mathrm{ns}}$ \\
\hline \multirow[t]{3}{*}{ Error } & $\mathrm{Se}$ & \multirow{3}{*}{18} & 0.002 & 0.014 & 0.002 & 0.002 & 0.001 \\
\hline & As & & 0.068 & 0.011 & 0.001 & 0.001 & 0.002 \\
\hline & Mo & & 0.016 & 17.597 & 0.108 & 0.167 & 0.153 \\
\hline
\end{tabular}

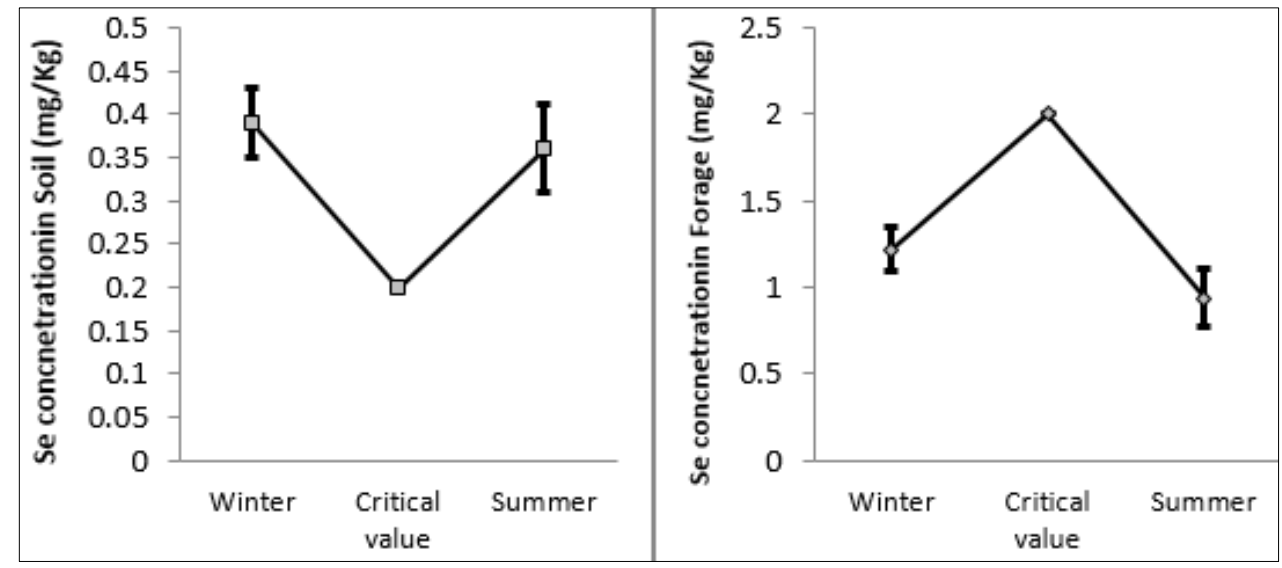

Figure 1. Selenium level fluctuations in soil and forage at different sampling seasons

Arsenic level in soil did not display much variation $(p>0.05)$ with respect to the seasons (Table 1). There was slight seasonal variation in As concentration in soil (winter, $3.19 \mathrm{mg} / \mathrm{kg}$; summer, 3.06 $\mathrm{mg} / \mathrm{kg}$ ) (Figure 2). Lower As levels were reported in current study compared to the critical concentration of $20 \mathrm{mg} / \mathrm{kg}$ [16]. Soil evaluation revealed exceptionally high As content in Jhang city (12.01 to $14.89 \mathrm{mg} / \mathrm{kg}$ ) [11] compared to current study values. The concentration of other minerals (iron, aluminum, and phosphorous), soil type and $p \mathrm{H}$ of the soil $[17,18]$ also affect As level and mobility in soil layers. A drop in $p \mathrm{H}$ increases As leaching in soils [19]. Current As levels were safe for the grazing livestock of the area under study.

Molybdenum concentration exhibited negligible variation during the two sampling periods (Table 1) yielding non-significant results $(p>0.05)$. Mean Mo soil concentration in winter was $0.968 \mathrm{mg} / \mathrm{kg}$ while it showed slight decrease during summer season $(0.904 \mathrm{mg} / \mathrm{kg}$ ) (Figure 3). Critical level of Mo in soils is estimated to be $1 \mathrm{mg} / \mathrm{kg}$ [20] and current results were very close to this limit. Soil optimal levels given for Mo (1-2 mg/kg) by McDowell [21] make this element highly bioavailable for plants which potentially absorb high amounts of Mo ranging between 10 and $20 \mathrm{mg} / \mathrm{kg}$. On the other hand, Mo-deficient soils are rich in iron and have low $p \mathrm{H}$ and organic matter which affect its ability to retain Mo. Such soils require supplementation in the form of foliar sprays or seed treatments and application of fertilizers. 


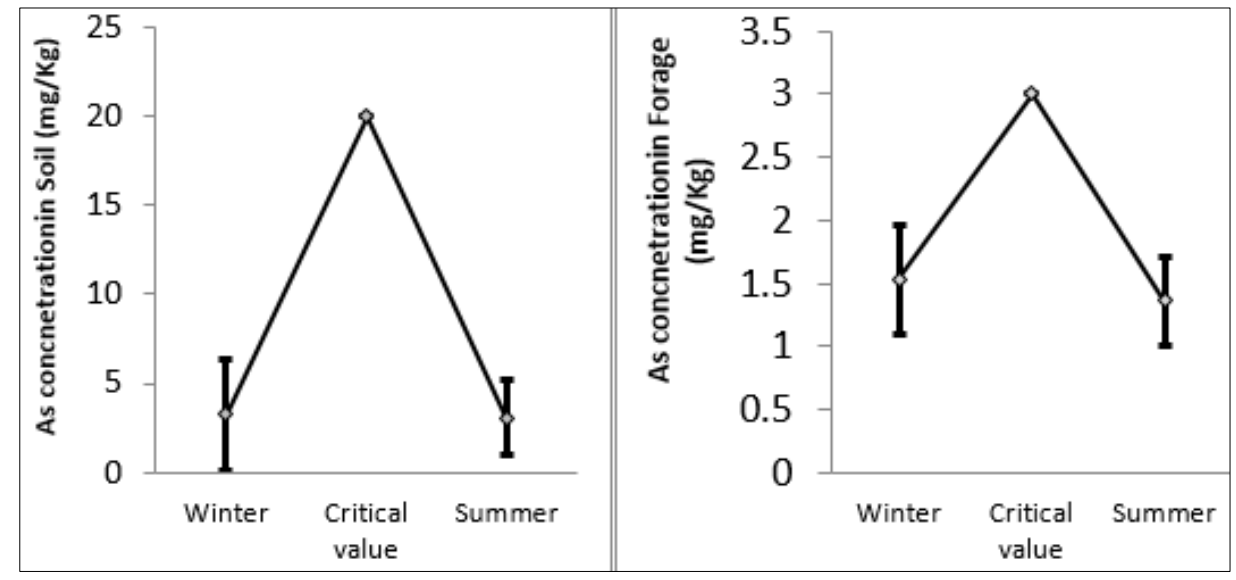

Figure 2. Arsenic level fluctuations in soil and forage at different sampling seasons

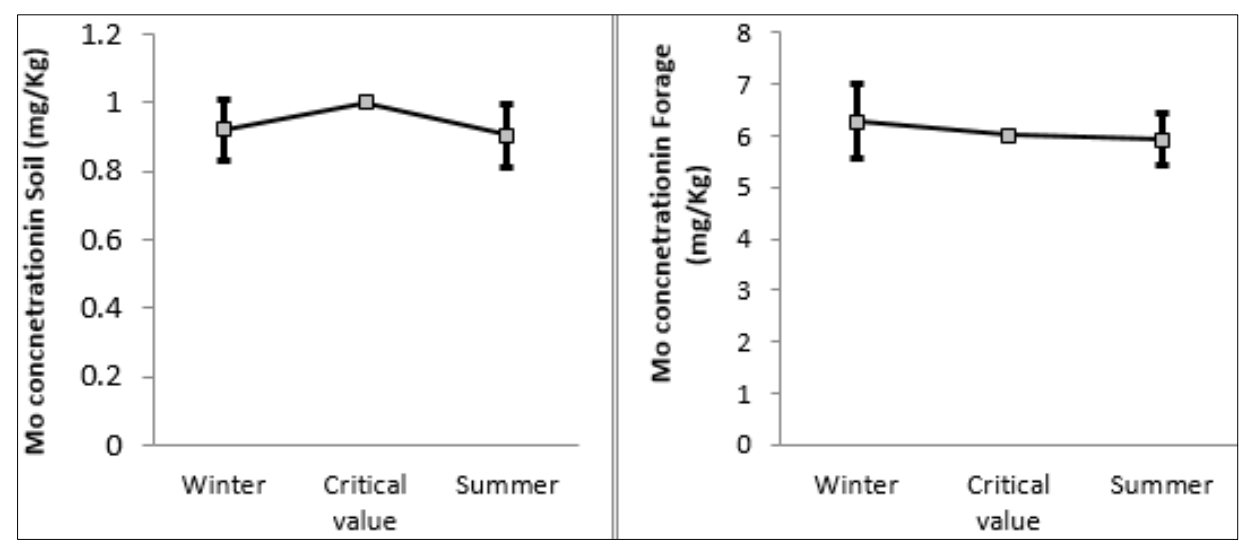

Figure 3. Molybdenum level fluctuations in soil and forage at different sampling seasons

\section{Forage}

The forage samples yielded non-significant variation $(p>0.05)$ in terms of two sampling seasons (Table 1) for Se concentration. Exhibiting high mean value in winter $(1.22 \mathrm{mg} / \mathrm{kg})$, the Se mean level dropped to $0.94 \mathrm{mg} / \mathrm{kg}$ in summer (Figure 1). Critical limit in plants, set for Se, is $0.1 \mathrm{mg} / \mathrm{kg}$ [22] and the current values were considerably higher than this concentration. It could be deduced that plants absorbed quite high levels of Se from soil of the study area. McDowell et al. [23] and Khan et al. [12] obtained lower values for Se in plants compared to the current study whereas, similar observations have been reported in Colombia [24] and Pakistan [11, 25].

ANOVA analysis displayed non-significant variation $(p>0.05)$ in the mean concentration of As in forage during winter and summer (Table 1). Winter mean level in forage $(1.53 \mathrm{mg} / \mathrm{kg}$ ) was higher than the summer mean level $(1.36 \mathrm{mg} / \mathrm{kg}$ ) (Figure 2). The forage plants had As values lower than the critical limit of $3 \mathrm{mg} / \mathrm{kg}$ [16]. High As values (1.82-1.91 mg/kg) in forage samples were exhibited in adjoining city of Jhang in another study [11]. Arsenic methylation in plants potentially reduces the risks associated with high As ingestion [26]. Higher levels of soil As result in decreased plant growth [27].

Insignificant change $(p>0.05)$ in Mo forage concentration was observed in the sampling seasons (Table 1). Two sampling intervals depicted a range of 5.9 to $6.2 \mathrm{mg} / \mathrm{kg}$ Mo in forages under study; winter season values were relatively higher than values obtained for summer season (Figure 3). Current winter Mo levels in the plants exceeded the critical level $(6 \mathrm{mg} / \mathrm{kg})$ [28] of Mo in plants whereas, the mean Mo level in summer remained close to this limit. Around $65 \%$ of the samples displayed Mo deficiency in forages. Nearly similar observations were made by McDowell et al. [23], 
Merkel et al. [29] and Hornick et al. [30] in Florida. Soil $p \mathrm{H}$ substantially affects the uptake of Mo by plants [31]. Metal bioavailability also increases with high organic content and moisture in soil [32].

\section{Serum}

Significant variation $(p<0.05)$ was observed in serum levels of Se in calves and non-lactating buffaloes while lactating group showed nearly similar Se concentration $(p>0.05)$ in both sampling seasons (Table 1). Mean Se levels varied between 0.017 and $0.028 \mathrm{mg} / \mathrm{L}$ in all buffalo cohorts in winter while in summer season, Se concentration remained between 0.012 and $0.024 \mathrm{mg} / \mathrm{L}$ (Figure 4) displaying high mean levels in winter season. Critical limit set for serum Se concentration $(0.03 \mathrm{mg} / \mathrm{L})$ [28] was higher than the present study findings. $90 \%$ of the samples displayed Se deficiency in lactating buffaloes while the other two groups (non-lactating and calves) were $100 \%$ deficient for Se. High Se level may result in multiple toxicities in the grazing animals such as skin cracks, emaciation, gangrene of extremities, hoof detachment; high Se level in buffaloes may even be fatal [33]. Deore et al. [34] found lower Se levels in their study on animals in comparison to current study. Similar Se levels were exhibited for buffalo plasma $(0.02 \mathrm{mg} / \mathrm{kg})$ at Jhang [11]. Selenium is a beneficial trace element for animal bodies and plays role in growth, fertility, antibody production and function of lymphocytes and neutrophils. Rats and pigs having Se deficiency exhibit hepatic apoptosis; ruminants, on the other hand display different clinical signs of poor antibody response, impaired immunity, embryonic mortality, white muscle disease [35].

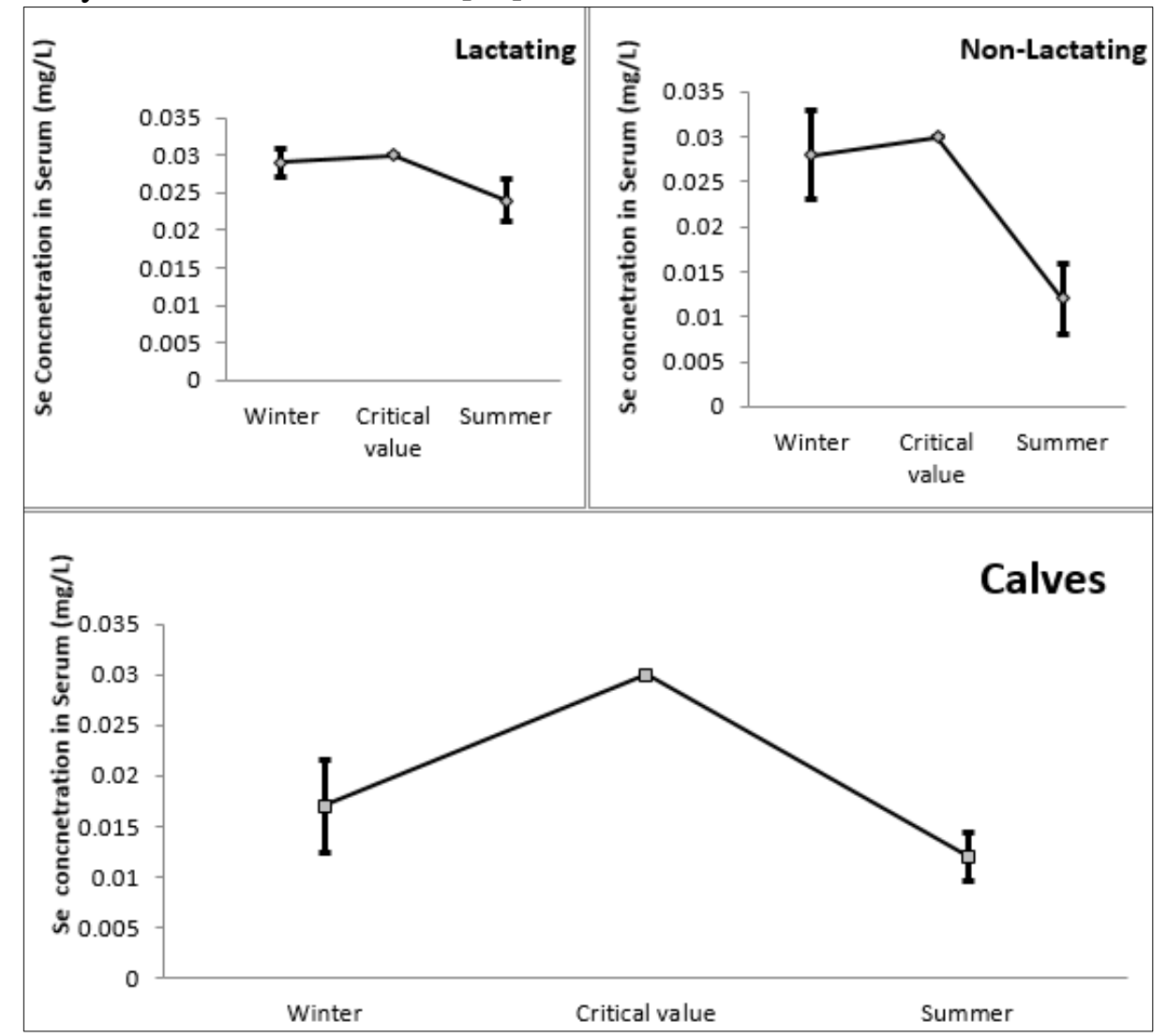

Figure 4. Selenium level fluctuations in serum at different sampling seasons

Heterogeneous distribution of As in Niliravi buffaloes was evident through significant variation $(p<0.05)$ with respect to sampling seasons in dry buffaloes, whereas, the lactating buffaloes and calves exhibited non-significant variation $(p>0.05)$ during the two sampling intervals (Table 1). Mean winter levels $(0.023-0.069 \mathrm{mg} / \mathrm{L})$ were higher than the summer season $(0.020-0.064 \mathrm{mg} / \mathrm{L})$ for as (Figure 5). Current study values were below the toxic limit $(1 \mathrm{ppm})$ for As [36]. All samples from the three buffalo cohorts were 100\% deficient for As. Kinacid and Hodgson [37] found lower mean values for 
as while Anke et al. [38] observed higher mean concentrations for as in comparison to current observations. Buffaloes at Jhang city had higher As content $(0.91-0.94 \mathrm{mg} / \mathrm{kg})$ in their blood plasma [11] in contrary to current findings. No imminent threat was found for studied livestock with respect to As concentration.
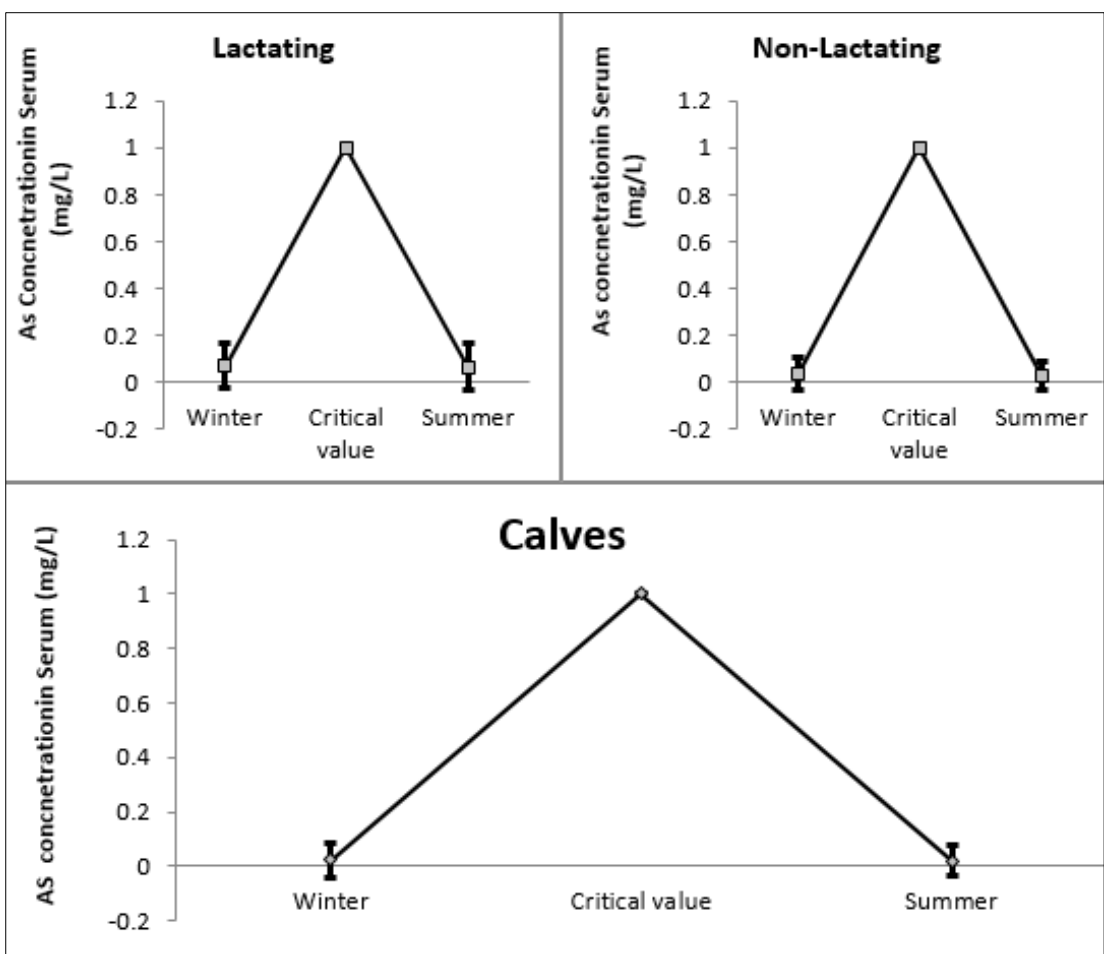

Figure 5. Arsenic level fluctuations in serum at different sampling seasons

The concentration of Mo varied significantly $(p<0.05)$ in all the buffalo categories with respect to sampling intervals (Table 1). Following the pattern of high serum levels in winter season, the mean concentration of Mo varied between 2.61 and $2.70 \mathrm{mg} / \mathrm{L}$ while in summer season, the range remained between 1.82 and $2.26 \mathrm{mg} / \mathrm{L}$ (Figure 6). Clawson et al. [39] reported the toxic levels of Mo as 5 ppm; current observations were considerably below this toxic limit. Current study values were lower than the standard values [22]. No imminent threat was found for studied livestock with respect to Mo concentration.

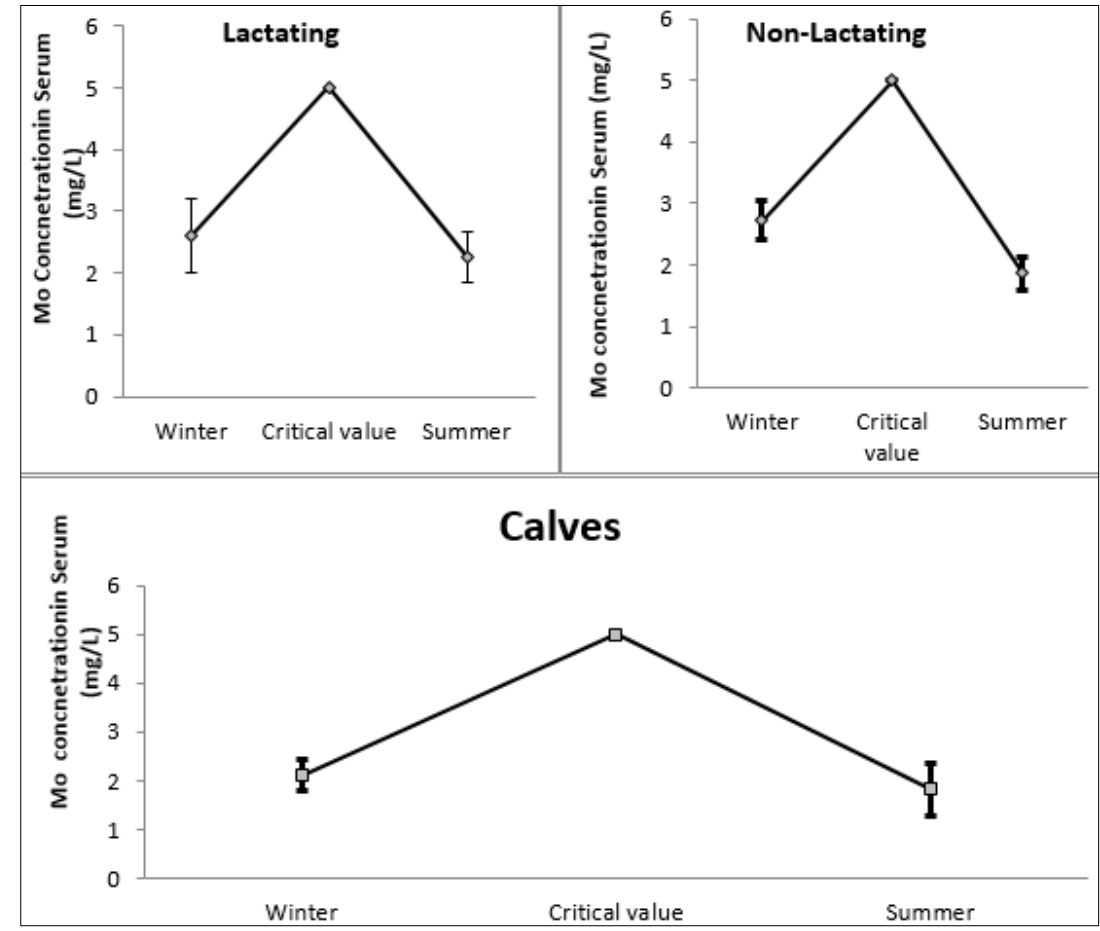

Figure 6. Molybdenum level fluctuations in serum at different sampling seasons 


\section{Correlation}

Positive but non-significant correlation was observed for the three mediums under study (forage, soil, serum) to determine potential toxicity of Se revealing bioavailability and balance of flow. On the other hand, As had significantly positive correlation between serum and forage manifesting direct accumulation of As in animal bodies after forage consumption. Mo exhibited negative and nonsignificant correlation for forage-serum and soil-forage while non-significant but positive value was observed for serum and soil (Table 2) indicating probable deficiency and low cross-transmission.

Table 2. Correlation among metal between Soil-Forage-Serum

\begin{tabular}{|c|c|c|c|}
\hline Metal & Soll-Forage & Forage-Serum & Soll-Serum \\
\hline $\mathrm{Se}$ & 0.379 & 0.145 & 0.407 \\
\hline $\mathrm{As}$ & 0.260 & 0.251 & $0.479(*)$ \\
\hline $\mathrm{Mo}^{--}$ & -0.145 & $0.367^{-}$ & -0.089 \\
\hline
\end{tabular}

Table 3. Bio concentration factor for metals from soil- forage-serum

\begin{tabular}{|c|c|c|c|c|c|}
\hline \multirow{2}{*}{ Metals } & Sampling Seasons & Soil to Forage & \multicolumn{3}{|c|}{ Forage to Serum } \\
\cline { 3 - 5 } & & & Lactating Buffalo & $\begin{array}{c}\text { Non Lactating } \\
\text { Buffalo }\end{array}$ & Buffalo claves \\
\hline Se & Winter & 3.1282 & 0.0237 & 0.0229 & 0.0139 \\
& Summer & 2.6038 & 0.0255 & 0.0127 & 0.0127 \\
\hline As & Winter & 0.4722 & 0.0450 & 0.0228 & 0.0150 \\
\hline Mo & Summer & 0.4444 & 0.0470 & 0.0191 & 0.0147 \\
\hline & Winter & 68.197 & 0.0433 & 0.0334 \\
\hline
\end{tabular}

\section{Bio-concentrationfactor (BCF)}

$\mathrm{BCF}$ for Se (soil to forage) in winter (3.128) was higher than the summer season (2.603). Comparatively, BCF was quite low between forage and serum for all buffalo categories; BCF ranged from 0.013 to 0.023 in winter while in summer, its range was 0.012 to 0.025 . Only lactating buffaloes displayed higher summer BCF (0.025) for Se. BCF for arsenic manifested low values between soil and forage in both winter (0.472) and summer (0.444). High transfer rate of metals from forage to nonlactating buffaloes was observed in winter (0.022) while in case of lactating buffaloes, high BCF was observed in summer (0.047). Interestingly, Mo exhibited unusually high BCF from soil to forage indicating high metal uptake in both winter (68.197) and summer (65.641).

However, BCF for Mo between forage and serum of buffaloes was almost similar to other metals. Winter BCF values for all buffalo categories were comparatively higher than summer season ranging between 0.0313 and 0.0433 .

Over all high $\mathrm{BCF}$ values in winter season corresponded to efficient metal transfer and low resistance in forage varieties. Lower BCF could be due to limited absorption capacity of plants or animals [25]. Environmental factors, seasonal influence, age and type of plant, $p \mathrm{H}$ and type of soil could potentially affect metal uptake and transfer among different media.

\section{Conclusions}

Presence of hazardous minerals in three major components (soil, forage and buffalo serum) was evaluated for determining extent of metal contamination in Sargodha, Pakistan. Ten soil and forage samples for each season were taken from ten randomly selected sites. 30 grazing buffaloes of 'niliravi' breed (calves, non-lactating and lactating) were also sampled randomly from these sites for collection of serum. Heavy metal quantification via atomic absorption spectrophotometry was carried out for selenium, molybdenum and arsenic. Non-significant but positive correlation was found for selenium (Se) concentrations in soil, forage and serum and molybdenum (Mo) concentrations in soil and serum. Negative correlation ( $>0.05)$ was obtained for Mo level between forage-serum and soil-forage which 
was indicative of molybdenum deficiency in the soil. The results suggested that the heavy metals remained below maximum permissible levels and were non-toxic for the ruminants of the study area.

Ethics: All the study protocols were approved by the Institutional Animal Ethics Committee, University of Sargodha (Approval No.25-A18 IEC UOS). All the experiments performed complied with the rules of National Research Council [40] and all methods were performed according to relevant guidelines and regulations.

\section{References}

1.MCDOWELL, L.R. Assessment of mineral status of grazing ruminants. World Rev. Anim. Prod., 33, 1987, p. 19-32.

2.ALI, W., ALI, M., AHMAD, M., DILAWAR, S., FIRDOUS, A., AFZAL, A. Application of Modern Techniques in Animal Production Sector for Human and Animal Welfare. Turk. J Agric., 8(2), 2020, p. 457-463. https://doi.org/10.24925/turjaf.v8i2.457-463.3159

3.MURRAY, R.K., GRANNER, D.K., MAYES, P.A., RODWELL, V.W. Harper's Biochemistry, $25^{\text {th }}$ Edition, McGraw-Hill, Health Profession Division, USA, 2000.

4.HAYS, V.W., SWENSON, M.J. Minerals and Bones. In: Dukes' Physiology of Domestic Animals $10^{\text {th }}$ edition, 1985 , p. $449-466$

5.DEOSTHALE, Y.G. Molybdenum content of some common Indian foods. Ind. J. Nutr. Dietet., 1990, p. 15-19.

6.SANCHEZ, P.A. Properties and Management of Soils in Tropics, John Wiley and Sons, New York, USA, 1976, p. 97-101.

7.LINDSAY, W.L., NORVELL, W.A. Development of DTPA soil test for Zn, Fe, Mn and Cu. Soil Sci. Soc. Am. J., 42, 1978, p. 421-428.

8.WELSCH, F.P., CROCK, J.G., SANZOLONE, R. Trace elements determination of arsenic and selenium using continuous-flow hydride generation atomic absorption spectrophotometry (HG-AAS). In: Arbogast, B. F. (ed) Quality assurance manual for the Branch of Geochemistry. Reston, VA: US Geological Survey, 1990, p. 38-45.

9.STEEL, R.G.D., TORRIE, J.H. Principles and procedures of statistics. $A$ Biometrical approach. $2^{\text {nd }}$ edition, 1980, McGraw Hill Book Co. New York, USA.

10.MCDOWELL, L.R., CONRAD, J.H., ELLIS, G.L. Mineral deficiencies and imbalances and their diagnosis. In: Symposium on Herbivore Nutrition in Subtropics and Tropics (Eds.): F.M.C. Gilchrist and R.I., 1984, Mackie University of Pretoria, South Africa, p. 67-88.

11.KHAN, Z.I., UGULU, I., UMAR, S., AHMAD, K., MEHMOOD, N., ASHFAQ, A., BASHIR, H., SOHAIL, M. Potential Toxic Metal Accumulation in Soil, Forage and Blood Plasma of Buffaloes Sampled from Jhang, Pakistan. Bull. Environ. Contam. Toxicol., 101, 2018, p. 235-242.

https://doi.org/10.1007/s00128-018-2353-1

12.KHAN, Z.I., HUSSAIN, A., ASHRAF, M., VALEEM, E.E., JAVED, I. Evaluation of variation of soil and forage minerals in pasture in a semiarid region of Pakistan. Pak. J. Bot., 37, 2005, p. 921-931.

13.KHAN, Z.I., AHMED, K., ASHRAF, M., VALEEM, E.E., JAVED, I.A Comparative Study on Mineral Status of Blood Plasma of Small Ruminants and Pastures in Punjab, Pakistan. Pak. J. Bot., 40, 2008, p. 1143- 1151.

14.KUNLI, L., LIRONG, X., JIAN'AN, T., LIANHUA, X. Selenium source in the selenosis area of the Daba region, South Quinling mountain, China. Environ. Geo.,45, 2004, p. 426-432.

15.FORDYCE, F. Selenium deficiency and toxicity in the environment. In: O. Selinus, B. Alloway, J.A. Centeno, R. B. Finkelman, R. Fuge, U. Lindh and P. Smedley (eds.), 2005, Elsevier Academic Press, London, United Kingdom, p.373-415.

16.O'NEILL, P. In Alloway, B. J. (ed.), Heavy Metals in Soils, 1995, Blackie Academic and Professional, London, United Kingdom. 
17.PIERCE, M. L. AND MOORE, C. B.Adsorption of arsenite and arsenate on amorphous iron hydroxide. Water Res., 16(7), 1982, p.1247-1253.

18.MOK, W. M. AND WAI, C. M. In: Nriagu, J. O. (ed.), Arsenic in the Environment, Part I, 1994, John Wiley and Sons, New York, USA.

19.BOWELL, R. J. Sorption of arsenic by iron oxides and oxyhydroxides in soils. Appl. Geochem., 9(3), 1994, p. 279-286.

20.O'CONNOR, G.A., BROBST, R.B., CHANEY, R.L., KINCAID, R.L., MCDOWELL, L.R., PIERZYNSKI, G.M., RUBIN, A., RIPER, G.G.V. A modified risk assessment to establish molybdenum standards for land application of bio-solids. J. Environ. Qual.,30, 2001, p. 1490-1507.

21.MCDOWELL, L.R. Nutrition of Grazing Ruminants in Warm Climates. 1985, Academic Press New York, p. 443.

22.***National Research Council. Nutrient requirements of domestic animals. National Academy of Sciences National Research Council. 1984, Washington, DC.

23.MCDOWELL, L.R., KIATOKO, M., BERTRAND, J.E., CHAPMAN, H.L., PATE, F.M., MARTIN, F.G., CONRAD, J.H. Evaluating the nutrition status of beef cattle from four soil order regions of Florida: II. Trace minerals. J. Anim. Sci., 55, 1982, p. 38-47.

24.PASTRANA, R., MCDOWELL, L.R., CONRAD, J.H., WILKINSON, N.S. Macro-mineral status of sheep in the Paramo region of Colombia. Small Rumin. Res., 5, 1991, p. 9-21.

25.AHMAD, K., KHAN, Z.I., JABEEN, H., ASHRAF, M., SHAHEEN, M., RAZA, S.H. Assessment of heavy metals and metalloids toxicity in buffaloes fed on forages irrigated with domestic wastewater in Bhalwal, Sargodha, Pakistan. Pak. J. Zool., 45, 2013, p. 1629-1637.

26.NISSEN, P., BENSON, A. Arsenic metabolism in fresh-water and terrestrial plants.Physio. Plant.,54, 1982, p. 446-450.

27.***CCME2001. Canadian soil quality guidelines for the protection of environmental and human health: Arsenic (inorganic) (1997). Updated In: Canadian environmental quality guidelines, 2001, Canadian Council of Ministers of the Environment, Winnipeg.

28.MCDOWELL, L.R. Minerals for Grazing Ruminants in Tropical Regions. Extension Bulletin, Anim. Sci. Dept. Centre for Trop. Agric., Univ. Florida. 1997, p. 81.

29.MERKEL, R.C., MCDOWELL, L.R., POPENOE, H.L., WILKINSON, N.S. Mineral status comparisons between water buffalo and Charolais cattle in Florida. Buffalo J., 1, 1990, p. 33-41.

30.HORNICK, S.B., BAKER, D.E., GUSS, S.B. Molybdenum in the environment. 1977, Marcel Dekker, New York, USA.

31.ANKE, M.Essential and toxic effects of macro, trace and ultra-trace elements in the nutrition of animals. In: Merian E, Anke M, Ihnat M, Stoeppler M (eds.) Elements and their compounds in the environment, $2^{\text {nd }}$ edition, 2004, Wiley-VCH Verlag, Weinheim, p. 305-341.

32.PARISH J, RHINEHART J. Mineral and vitamin nutrition for beef cattle. 2016, Agricultural Communications, Mississippi State University Extension Service, Mississippi, USA, p. 1-16.

33.GHOSH, A., SARKAR, S., PRAMANIK, A. K., CHAUDHARY, P.S., GHOSH, S. Selenium toxicosis in grazing buffaloes and its relationship with soil and plant of West Bengal. Indian Journal of Animal Sciences, 63, 1993, p. 557-560.

34.DEORE, M. D., SRIVASTAVA, A. K., SHARMA. S. K. Effect of reduced glutathione treatment onselenosis, blood selenium concentration and glutathione peroxidase activity after repeated short term selenium exposure in buffalo calves. Toxicol., 213, 2005, p. 169-174.

35.SWECKER, W. S. Selenium and immune function in cattle. Compendium: Food Animal. 1997, p. 248-253.

36.PUIS, R. Veterinary trace mineral deficiency and toxicity information. Canada Department of Agriculture. 1981, publication 5139, Ottawa, Canada.

37.KINCAID, R. L., HODGSON, A.S. Relationship of selenium concentrations in blood of calves to blood selenium of the dam and supplemental selenium. J. Dairy Sci., 72, 198, p.259-263. 
38.ANKE, M., GRUN, M., PARTSCHEFELD, B.,GROPPE, L., HENNING, A. Essentiality of arsenic. In: M. Kirchgessner (Ed.) Trace Element Metabolism in Man and Animals, Institut fur Ernahrungsphysiologie, TechnischeUniversitatMunchen, Freising, Fed., Germany, 3, 1978, p. 248.

39.CLAWSON, W. J., LESPERANCE, A. L., BOHMAN, V. R., LAYHEE, D. C. Interrelationship of dietary molybdenum and copper on growth and tissue composition of cattle. J. Anim. Sci.,34, 1972, p.516-20.

40.***National Research Council. Guide for the care and use of laboratory animals. Washington, d.c., National Academy press. (1996)

Manuscript received: 12.05 .2020 